\title{
PENERAPAN DISIPLIN POSITIF OLEH GURU DENGAN INTEGRASI IMAN KRISTEN PADA KELAS I-A DI SEKOLAH DASAR X SURABAYA
}

\author{
Betharia Krisdianti*, Yuli Christiana Yoedo \\ Program Studi Pendidikan Guru Sekolah Dasar, Universitas Kristen Petra \\ Jl. Siwalankerto 121-131, Surabaya \\ E-mail: *g11170001@john.petra.ac.id; ${ }^{2}$ yulichy@ petra.ac.id \\ *Penulis korespondensi
}

\begin{abstract}
ABSTRAK
Murid akan menjadi penerus bangsa, maka murid perlu memiliki karakter yang baik dan benar. Karakter baik ini akan tumbuh bila guru menerapkan pembelajaran yang baik dan benar. Namun banyak guru yang masih belum menerapkan proses pembelajaran dan penerapan disiplin yang benar. Penelitian ini bertujuan untuk menjelaskan cara menerapkan disiplin kepada murid kelas I-A SD dengan menggunakan prinsip disiplin positif dan integrasi Iman Kristen pada siswa kelas I-A SD di Sekolah Dasar Kristen 'X' Surabaya. Melihat kasus kekerasan oleh guru dengan alasan disiplin, diharapkan penelitian ini memberi gambaran baru akan pola disiplin yang tidak menggunakan kekerasan. Penelitian ini menggunakan metode penelitian kualitatif. Guru Bahasa Inggris di kelas I-A menjadi subjek penelitian. Peneliti melakukan observasi terhitung dari bulan Agustus hingga bulan November, dan melakukan wawancara kepada subjek penelitian. Peneliti juga mengkonfirmasi data bersama wali kelas sebagai informan. Data tersebut diolah dengan menggunakan teori disiplin positif dan disiplin positif dari sudut pandang Iman Kristen dan analisis dari peneliti. Peneliti menguji apakah penerapan dapat diterima oleh murid dengan baik atau tidak, peneliti membagikan kuisioner untuk melihat respon dari murid kelas I-A. Peneliti memberi pertanyaan mengenai "apakah murid sudah mentaati peraturan yang berlaku?" sebanyak $90 \%$ menjawab sudah mentaati. $10 \%$ belum, peneliti melihat hasil observasi dan wawancara dengan subjek penelitian, melihat ada faktor dari diri murid yang membuat murid belum bisa mentaati peraturan. Perolehan data murid yang mampu mentaati perturan menunjukkan lebih dari $50 \%$. Jadi dapat disimpulkan bahwa penerapan yang dilakukan guru Bahasa Inggris di kelas I-A ini mampu menolong murid memiliki sikap disiplin.
\end{abstract}

Kata kunci: Disiplin Positif, Integrasi Iman Kristen, Siswa kelas 1 Sekolah Dasar.

\section{ABSTRACT}

Students will become the nation's successor, so students need to have good and wise character. This good character will grow if the teacher applies good and appropriate learning. However, many teachers still have not applied the learning process and the appropriate application of discipline. This research aims to describe the appclication to discipline to grade I-A elementary school students by using the principle of positive discipline and the integration of Christian faith in grade I-A elementary school students in " $X$ " Christian Elementary School Surabaya. As we remember nowadays there are more 
cases regarding violents in elementary students instead of disciplining the students, behavior. The researcher hope that this study will give another disciplining method without violence. This study used qualitative research methods. The English teacher in class I-A is the subject of research. Researchers made observations from August to November, and conducted interviews with research subjects. Researchers also conducted data with the homeroom teacher as informants. The data is processed using positive discipline theory and positive discipline from the point of view of the Christian Faith and analysis from researchers. Researchers applying the application can be accepted by students well or not, the researcher gives a questionnaire to see the responses of class I-A students. Researchers ask questions about "have the students obeyed the applicable rules?" as much as $90 \%$ answered that they had complied. 10\% not yet, researchers looked at the results of observations and interviews with research subjects, saw factors from students that made students unable to obey the rules.. $10 \%$ of students have not been able to do well, the researcher looked at the results of observations and interviews with research subjects, and saw that there were some factors from students that prevent them to obey the rules. Data on students who are able to obey rules show more than 50\%. Thus, it can be concluded that the application of the English teacher in class I-A is able to help students have a disciplined attitude.

Keywords: Positive discipline, integration of christian values, elementary students grade $I$.

\section{PENDAHULUAN}

Kekerasan pada anak SD masih menjadi kasus hangat dalam dunia pendidikan. Tercatat lebih dari 100 kasus mengenai kekerasan sejak awal tahun 2018 hingga pertengahan bulan Juli (Okezone, 2018). Berdasarkan data, kasus kekerasan fisik masih bertambah menjadi 127 kasus mencakup kekerasan secara fisik, psikis, dan seksual yang terjadi pada awal bulan Januari hingga Oktober 2019 (Tempo, 2019). KPAI (Komisi Perlindungan Anak dan Ibu) berupaya menekan kasus kekerasan dengan membuat program sekolah ramah anak. Program KPAI tersebut merupakan model pembelajaran yang bertujuan memastikan siswa dapat belajar dengan aman dan nyaman baik secara fisik dan psikis.

Program KPAI dengan sekolah ramah anak merupakan upaya untuk menekan kasus kekerasan yang masih terjadi pada anak. Program ini dilaksanakan kebanyakan di sekolah negeri, sedang sekolah swasta memiliki program tersendiri yang tetap memiliki tujuan dan penerapan yang sama. Program ini sejalan dengan definisi dan tujuan dari disiplin positif. Menurut Febriandari (2017) definisi disiplin positif adalah metode yang menekan perilaku kekerasan dalam mendisiplinkan siswa. Dalam mendisiplinkan murid jenjang SD diperlukan metode yang tepat. Metode yang tepat merupakan metode yang tidak menggunakan kekerasan dan memunculkan nilai karakter yang baik untuk bekal anak ketika anak beranjak dewasa (Febriandari, 2017). Pentingnya menerapkan disiplin positif diharapkan akan menumbuhkan generasi yang berkarakter.

Perilaku tidak disiplin dapat terjadi akibat dari penerapan disiplin yang digunakan kurang efektif. Guru memiliki peran penting dalam mendidik, memotivasi, menolong dan mengarahkan murid untuk bertanggung jawab atas dirinya (Shabir, 2015). Dalam penerapan disiplin ada berbagai cara. Salah satu penerapan disiplin adalah disiplin negatif atau corporal punishment. Corporal punishment merupakan bagian dari pembelajaran yang dianggap efektif dan 
praktis dalam menuntut kepatuhan murid (Windari, 2015). Pada tahun 1979, Swedia mengupayakan agar sistem ini dihapuskan. Orang-orang melihat bahwa sistem corporal punishment ini mengakibatkan hal negatif pada perkembangan anak mulai dari luka fisik hingga keterbelakangan mental anak. Sejak saat itu, guru dipercayakan untuk mendidik murid dalam aspek kognitif dan rohani (Windari, 2015).

Murid berhak mendapat pendidikan dengan rasa aman dan nyaman di sekolah. Murid juga merupakan jiwa yang perlu dibimbing dan dituntun untuk semakin mengenal kebenaran. Sebagai guru Kristen, guru-guru memiliki panggilan khusus untuk mengintegrasikan kebenaran Alkitab ke dalam seluruh aspek pembelajaran dan menampilkan relevansi Firman Allah dalam kehidupan (New Hope International, 2015).

Terdapat penelitian terlebih dahulu dengan topik serupa. Imanuela Praba Aji \& Kimura Patar Tamba (2020) melakukan penelitian dengan judul "Penerapan Disiplin Positif dalam Pembelajaran Ditinjau melalui Perspektif Kristen". Penelitian ini menerapkan disiplin positif kepada murid kelas lima sekolah dasar yang berlokasi di Jakarta. Peneliti mendapati dampak dari penerapan disiplin positif dengan memberikan konsekuensi logis mengantisipasi anak tidak mengulangi hal yang salah. Perbedaan dalam penelitian Imanuela Praba Aji \& Kimura Patar Tamba dengan penelitian ini dapat dilihat dari subjek penelitian, dan lokasi penelitian. Penelitian ini fokus meneliti penerapan disiplin untuk anak kelas satu SD.

Penelitian selanjutnya dari Alit Kurniasari yang berjudul "Kekerasan Versus Disiplin dalam Pengasuhan Anak". Subjek dalam penelitian ini adalah orangtua dan guru. Lokasi dalam penelitian ini berlokasi di Jakarta, berbeda dengan peneliti yang berlokasi di Surabaya. Penelitian Alit Kurniasari fokus meneliti alasan mengapa orangtua dan guru memberikan disiplin dengan kekerasan. Hasil dari penelitian ini adalah menyarankan guru dan orangtua untuk menerapkan disiplin positif. Penelitian ini memiliki perbedaan dari segi lingkungan perkembangan anak dan dasar iman yang digunakan dalam metode penerapan disiplin positif. Perbedaan selanjutnya dapat dilihat dari subjek penelitian. Penelitian ini memaparkan alasan guru dan orangtua menerapkan kekerasan dalam mendisiplinkan murid dan anak.

Penelitian terdahulu selanjutnya dari Ayang Emiyati (2018) yang telah melakukan penelitian dengan judul "Mendisiplinkan Anak Menurut Prinsip Kristen". Dalam penelitian ini Ayang Emiyati melakukan studi literatur dan fokus menyajikan teori disiplin. Hasil penelitian ini mengatakan bahwa penggunaan tindakan pukulan dapat digunakan sebagai alternatif terakhir dalam proses pendisiplinan pada murid. Perbedaan penelitian Ayang Emiyati dengan penelitian ini adalah metode penelitian, peneliti menggunakan kualitatif untuk lebih menyampaikan makna dan membahas penerapan proses disiplin positif. Peneliti setuju akan teori yang dipaparkan, namun tidak setuju dengan penggunaan pukulan sebagai jalan terakhir mendisiplinkan murid.

Perbedaan dengan penelitian ini, khusus membahas penerapan disiplin positif bagi murid kelas satu sekolah dasar. Penerapan disiplin pada murid kelas satu perlu menggunakan strategi yang sesuai dengan perkembangan psikologis, kognitif, fisik, dan bahasa untuk anak SD kelas satu dengan usia 6 hingga 7 tahun. Menurut teori Piaget (1970, as cited in Gunarsa, 2012, p. 154) SD kelas 1 termasuk dalam kategori masa praoperasional. Anak-anak pada kategori ini menggunakan objek visual untuk dapat memahami lingkungan dengan kata-kata (Pratiwi, 2017) sehingga apa yang murid 
lihat dari guru, itu yang akan ditiru (Shihab, 2017).

Pada masa pra-operasional, setiap stimulus atau didikan yang diberikan mendorong murid mampu melakukan adaptasi yang sesuai dengan perubahan dan perkembangan secara berkelanjutan (Purnamasari, 2020). Dengan demikian penting bagi pendidik memberikan stimulus yang positif yang membangun dalam penerapan disiplin.

Salah satu sekolah yang menerapkan disiplin positif dengan mengintegrasikan iman Kristen adalah Sekolah Dasar Kristen ' $\mathrm{X}$ ' Surabaya. Berdasarkan hasil observasi dan wawancara pada 29 Oktober 2019, terdapat beberapa upaya yang dilakukan untuk mendisiplinkan murid. Upaya yang dilakukan guru untuk menumbuhkan sikap disiplin pada murid adalah guru selalu konsisten menerapkan disiplin positif dalam bentuk mengingatkan murid untuk taat peraturan.

Peneliti melakukan observasi pada tanggal 3 September 2019 di kelas IA di sekolah dasar Kristen ' $X$ ' Surabaya Timur, dengan jumlah murid 21 anak. Dalam peraturan termuat: (1) we respect God and each other; (2) we listen to our teacher attentively; (3) we use soft voice; (4) we raise our hands to speak; (5) we keep our place neat and clean. Peraturan tersebut terpajang di dalam kelas dan guru konsisten mengingatkan siswa untuk mentaatinya. Peraturan ini menolong murid untuk bisa memiliki sikap disiplin tanpa menggunakan kekerasan. Dengan demikian perilaku yang terbentuk adalah: murid tidak berbicara sendiri saat guru sedang mengajar, murid mengangkat tangan jika hendak menjawab, dan murid bisa menunggu dengan tenang agar bisa didengar guru. Peneliti ingin mengetahui lebih banyak ilmu mengenai penerapan disiplin positif dengan integrasi iman Kristen melalui sekolah ini.

\section{LANDASAN TEORI}

\subsection{Disiplin Positif}

Disiplin positif merupakan metode untuk menghapuskan hukuman saat mendisiplinkan murid (Wijaya, 2015). Hukuman yang dimaksudkan seperti memberi ancaman, mengambil barang milik murid, pengabaian, atau bentuk lain yang menyebabkan murid menderita baik secara fisik maupun psikologis. Disiplin positif mengajak murid untuk memahami sebabakibat dari perilaku yang mereka lakukan (Wijaya, 2015). Melalui disiplin positif murid dapat mempelajari cara menyelesaikan suatu masalah secara konstruktif, kreatif, dan memiliki empati pada orang lain.

Disiplin positif menurut Jane Nelsen, Lynn Lott, dan Stephen Glenn (2006; as cited in Burden, 2013), meliputi sebuah kebaikan, sikap hormat, ketegasan, dan sebuah dukungan. Dalam proses disiplin positif ini menggunakan 6 pendekatan sebagai berikut. Pendekatan pertama yakni menggunakan konsekuensi yang logis dan alami yang menjadi cara untuk memenangkan hati murid. Guru perlu memberikan konsekuensi yang logis dan alami. Perbedaan dari konsekuensi logis dan alami adalah konsekuensi logis merupakan konsekuensi yang sudah ditetapkan oleh guru. Sebaliknya, konsekuensi alami adalah akibat langsung yang dialami murid setelah melakukan sesuatu yang salah. Konsekuensi ini tidak berasal dari guru, namun guru berperan memberikan pengertian pada murid.

Jane Nelsen (2006; as cited in Burden, 2013) merangkum konsekuensi logis menjadi 3R. (1) Related to the behavior yang berarti pemberian konsekuensi harus berkaitan dengan perilaku yang menyimpang. Contohnya: Murid bermain pensil saat guru 
menjelaskan akibatnya murid tidak mendengarkan pembelajaran.

Konsekuensi yang diberikan adalah guru mengambil pensil tersebut dan bukan menghukum murid berdiri di depan kelas. (2) Respectful towards the child and not involve shame or blame. Artinya, dalam pemberian konsekuensi, guru tetap menghormati murid dan tidak memalukan murid. Contoh: Murid tidak mengerjakan PR, guru bisa mengatakan "kalau tidak mengerjakan PR dan mengumpulkan hari ini, apa yang harus kamu lakukan?". Dengan demikian guru tidak memberi label pada murid alihalih mengatakan hal yang memalukan murid. (3) Reasonable in both child's and parent's perspective. Artinya, pemberian konsekuensi diikuti dengan penjelasan dari sudut pandang murid dan guru. Contoh: Murid selama proses mengerjakan tugas bersama di kelas bermain sendiri sehingga tugas tidak selesai sebelum istirahat. Guru memberi pengertian "Kamu tadi tidak mengerjakan tugas bersama, jadi waktu istirahat kamu pakai untuk mengerjakan tugas yang belum terselesaikan." Hal itu terjadi atas kesepakatan antara murid dan guru.

Selanjutnya masih dari Jane Nelsen (2006; as cited in Burden, 2013), pendekatan kedua adalah memahami bahwa murid memiliki 4 tujuan dari perilaku tidak taat. Istilah "murid nakal itu biasanya butuh perhatian lebih" bukanlah hal yang baru dalam dunia pendidikan. Dalam pendekatan ini dijelaskan alasan murid melakukan hal yang menyimpang, dan bagaimana guru menanggapi dengan 4 cara yakni, mencari perhatian, menggunakan kekuatan, mengadakan pembalasan, dan sikap ketidakmampuan.

a. Mencari perhatian. Murid belum bisa mengenali dan mengungkapkan perasaannya. Sehingga perilaku yang ditunjukkan mengganggu kegiatan orang disekitarnya.

b. Menggunakan kekuatan. Murid dengan sengaja melakukan sesuatu yang membuat guru marah.

c. Mengadakan pembalasan. Murid yang merasa tidak mendapatkan apa yang mereka inginkan akan bertindak lebih parah.

d. Sikap ketidakmampuan. Murid menunjukkan sikap tidak mampu untuk menggiring guru memiliki simpati pada murid.

Pendekatan ketiga, menggunakan kebaikan dan ketegasan di waktu yang bersamaan ketika menghadapi sikap ketidaktaatan murid (Nelsen, 2006; as cited in Burden, 2013). Pengertian tegas dari Kamus Besar Bahasa Indonesia adalah jelas dan terang benar. Disiplin positif dengan menggunakan ketegasan berarti, guru memberi kejelasan dan bersifat membenarkan. Tegas diperlukan bagi murid yang belum menganggap peraturan adalah hal yang penting dan baik bagi dirinya.

Pendekatan ini menyampaikan bahwa penting untuk memiliki komunikasi yang baik dan tegas dalam penerapan disiplin positif. Kebaikan menunjukkan kasih sayang antara relasi guru dan murid. Ketegasan disini berbeda dengan kemarahan yang diungkapkan. Kemarahan adalah ungkapan emosi marah dan tidak memiliki tujuan mendidik. Ketegasan adalah ungkapan tegas tidak dengan teriak, melainkan emosi tenang dan memiliki tujuan.

Selanjutnya pendekatan keempat, mengizinkan murid dan guru memiliki relasi yang saling menghormati dan membangun (Nelsen, 2006; as cited in Burden, 2013). Tujuan pendekatan ini mengajak guru menjadi model bagi murid. Guru yang memiliki relasi dengan murid, menjadikan murid merasa nyaman dan timbul kepercayaan.

Pendekatanvkelima, 
mengembangkanbpertemuan

orangtua dengan murid untuk mendukung efektifitas penanganan sikap ketidaktaatan (Nelsen, 2006; as cited in Burden, 2013). Orangtua memiliki peran penting dalam pendidikan anak. Pertemuan guru dan orangtua dinilai efektif dalam menjaga penerapan disiplin dapat terjadi di rumah.

Terakhir, pendekatan keenam, menggunakan dorongan yang menginspirasi murid untuk mengoreksi diri sendiri (Nelsen, 2006; as cited in Burden, 2013). Pendekatan ini menekankan bahwa yang dimaksud adalah dorongan, bukan pujian. Pujian tidak mengajarkan murid untuk berani mengambil resiko. Sementara dorongan merupakan upaya yang fokus pada apresiasi dan mengembangkan usaha atau perbuatan murid. Contoh kalimat dorongan adalah "coba lihat nilai rapormu. Itu menunjukkan seberapa keras hasil usahamu".

\subsection{Siswa Kelas I Sekolah Dasar (usia 6 hingga 7 tahun)}

Ditinjau dari perkembangan bahasa anak usia 6 tahun, anak memiliki kemampuan meniru apa yang mereka lihat (Shihab, 2017). Teori perkembangan kognitif oleh Piaget (n.d) menyatakan bahwa anak pada rentang usia 2-7 tahun melakukan suatu perilaku dari hasil meniru orang di sekitarnya (Gunarsa, 2011, p. 154.). Jika guru menerapkan kedisiplinan dengan menggunakan kekerasan, maka anak akan menirukan hal tersebut pada orang lain. Hal ini akan menjadi masalah bila guru tidak memberi teladan yang benar mengingat guru masih dianggap sebagai sumber terpercaya dan panutan bagi siswa.

Dalam bukunya, Gunarsa (2011, p. 62) mengatakan bahwa penting bagi anak untuk mendapatkan dasar yang tepat. Dasar yang tepat ini bertujuan ketika anak beranjak dewasa, anak tidak mengalami gangguan secara emosi atau gangguan kognitif. Kebutuhan yang penting dalam masa perkembangan anak yaitu kasih sayang. Ketika anak tidak mencukupi kebutuhan tersebut, anak akan gagal dalam mempercayai orang lain dan berimbas pada kehidupan sosialnya (Gunarsa, 2011). Formative years atau 5 tahun pertama adalah masa emas anak. Masa yang tepat memberikan rangsangan positif dalam segala aspek hidupnya.

Anak yang sudah mendapat rangsangan positif untuk bekal dirinya, di kemudian hari anak mampu meningkatkan dan mengembangkan fungsi dari kepribadiannya (Gunarsa, 2011). Pemberian rangsangan positif oleh lingkungan dapat menjadi pengalaman bagi anak. Hal ini diperoleh melalui proses belajar yang meliputi proses pengamatan, latihan, dan pengulangan (Gunarsa, 2011, p. 120). Albert Bandura (n.d) menekankan pentingnya proses peniruan dalam kehidupan anak sehingga orangtua dan pendidik diharuskan menjadi contoh yang tepat. Ketika orangtua dan pendidik mampu mencontohkan yang tepat, anak dapat melihat standar baik dan tepat itu seperti apa.

\subsection{Disiplin Positif dalam Perspektif Iman Kristen}

Proses mengintegrasi tidak bisa dilihat sebagai suatu penolakan akan pengetahuan, melainkan menjadi proses mengklarifikasi, menyaring dan mengoreksi mana yang baik dan sesuai dengan perspektif iman Kristen (Harris, 2004, p. 22). Berdasarkan Kiki Debora dan Chandra Han (2020) tujuan mengintegrasikan iman Kristen dalam pembelajaran secara holistis, artinya bukan hanya di bidang pengetahuan secara akademik tetapi pendidikan yang mengajarkan kebenaran Alkitabiah pada siswa.

Manusia memiliki Roh Kudus dalam hatinya untuk memimpin hidupnya dalam kebenaran Allah. Allah Bapa senantiasa 
mendisiplinkan manusia ciptaan-Nya baik secara individual maupun kelompok dengan tujuan agar mereka hormat dan taat kepada-Nya (Hendra, 2018). Pada Alkitab Perjanjian Lama tertulis cara Tuhan mendisiplinkan umat-Nya sama seperti ayah mendisiplinkan anaknya. Pada Ulangan 8:5 "Maka haruslah engkau insaf, bahwa TUHAN, Allahmu, mengajari engkau seperti seseorang mengajari anaknya". Pada ayat ini dituliskan bahwa Allah mengajar kita karena Allah mengasihi manusia. Cara Tuhan mengasihi yaitu dengan memberi pengajaran, memberi teguran, menyatakan nasihat.

Dalam Perjanjian Lama tertulis dalam kitab Amsal 13:24 yang menyatakan ketika seseorang mengasihi anaknya, ia akan menghajar pada waktunya. Jika kita melihat satu ayat ini, maka timbul pemikiran bahwa cara mendisiplinkan "dianjurkan" oleh Alkitab dengan menghajar. Kata-kata dalam Perjanjian Lama, ditulis dalam bentuk puisi. Kita tidak bisa menelan mentah-mentah, kata-kata pada perjanjian lama. Kita perlu meminta hikmat Tuhan dan menggunakan sudut pandang yang unik dan luas. Memahami pesan Allah dalam kitab Perjanjian Lama memerlukan pemahaman konotatif dan pendekatan tertentu untuk menafsirkannya (Sitorus, 2018).

Alkitab di Perjanjian Baru dalam kitab Markus 6: 34 menyampaikan bahwa Tuhan Yesus melihat orang banyak dan hati-Nya tergerak oleh belas kasihan, lalu Tuhan Yesus mulai mengajarkan banyak hal. Dalam kitab Perjanjian Baru, berisikan sejarah dan kisah nyata kehidupan Tuhan Yesus, khususnya empat kitab pertama dalam Perjanjian Baru (Sitorus, 2018). Dalam Perjanjian Baru ini yang dapat kita lihat teladan yang Tuhan Yesus berikan pada kita sebagai guru untuk mengajar.

Berikut prinsip disiplin menurut sudut pandang Kristen dalam menerapkan disiplin positif. (Aji \& Tamba, 2020).

1. Guru dan siswa perlu membangun relasi yang meneladani Allah Tritunggal. Untuk itu guru dipercayakan Tuhan menjadi tangan kanan Allah dalam mengarahkan dan membimbing siswa.

2. Disiplin harus memulihkan. Disiplin sudah seharusnya dilakukan dengan penuh kasih yang memulihkan. Kasih itu hanya berasal dari Tuhan Yesus satu-satunya. Kasih itulah yang menuntun siswa kembali ke jalan yang benar (van Brummelen, 2009). Tuhan begitu mengasihi anak-anakNya. Ketika satu dari seratus domba hilang, Tuhan mencari dan bawa kembali dengan penuh sukacita.

3. Kasih yang mencakup perhatian, keprihatinan, belas kasih dan kerinduan untuk memulihkan hubungan yang rusak akibat tindakan yang menyimpang. Demikian kasih harus menjadi gambaran dari disiplin (van Brummelen, 2009).

Alkitab memaparkan standar bagi setiap orang agar dapat menilai kebudayaannya masing-masing. Manusia hidup dalam zaman modern, dengan semua tawaran kemudahan. Dalam hal ini tidak berarti manusia menolak budaya dunia. Namun bagaimana manusia, baik pendidik, orangtua, maupun siswa, menerima hikmat dari Tuhan dan dibantu dengan pimpinan Roh Kudus untuk memilah mana yang berkenan bagi Allah (New Hope International Limited, 2015).

\section{METODE PENELITIAN}

\subsection{Desain Penelitian}

Berdasarkan data yang ada, penelitian ini menggunakan pendekatan kualitiatif. Pada penelitian ini memaparkan hasil observasi, wawancara, dan hasil kuesioner. Penelitian ini menyampaikan penerapan disiplin secara positif yang dituangkan dalam bentuk 
deskripsi. Penelitian kualitatif menyajikan fenomena yang dialami peneliti. Fenomena meliputi perilaku, motvasi, sudut pandang, dan sebagainya berdasarkan pendidikan Kristen.

Penelitian ini menunjukkan makna dari penerapan disiplin positif yang ada di sekolah dasar Kristen ' $\mathrm{X}$ ' Surabaya. Proses observasi menjelaskan faktor yang mendukung penerapan disiplin positif, aktivitas apa yang penting dalam menerapkan disiplin positif. Penelitian ini menekankan tujuannya untuk menangkap makna di balik suatu fenomena, bukan untuk menguji teori.

\subsection{Subjek Penelitian}

Subjek penelitian dalam penelitian ini merupakan guru Bahasa Inggris kelas I-A Sekolah Dasar Kristen ' $\mathrm{X}$ ' Surabaya dan wali kelas I-A Sekolah Dasar Kristen ' $X$ ' Surabaya sebagai informan penelitian. Informan penelitian membantu mengkonfirmasi kebenaran data dari subjek penelitian.

\subsection{Analisis Data}

Penelitian ini menggunakan pendekatan kualitatif. Dengan menggunakan metode observasi di sekolah, wawancara dengan subjek dan informan penelitian, serta membuat kuisioner untuk melihat respon murid kelas I-A terhadap penerapan disiplin yang diterapkan oleh guru Bahasa Inggris.

\section{HASIL DAN PEMBAHASAN}

Peneliti memaparkan data mengenai penerapan disiplin positif yang dilakukan oleh guru dengan integrasi iman Kristen. Data ini meliputi perilaku guru, perkataan yang disampaikan oleh guru, dan respon murid dalam menanggapi penerapan yang dilakukan oleh guru. Berikut adalah uraian temuan data peneliti.

\subsection{Peraturan yang Berlaku dalam Kelas I-A Sekolah Dasar X Surabaya}

Di sekolah dasar Kristen ' $X$ ' ini memiliki peraturan. Peraturan kelas yang disepakati sekolah telah terintegrasi dengan konsep disiplin positif. "Peraturan dan karakter murid itu saling terintegrasi karena kita menganut positive discipline itu juga kan jadi itu untuk membentuk karakter anak, sehingga itu saling terintegrasi" (Bunga, personal communication, October 27, 2020). Peraturan kelas bertujuan untuk menolong murid memiliki sikap disiplin. Peraturan yang tertulis sebagai berikut:

1. We respect God and others.

2. We listen to our teachers attentively.

3. We use soft voice.

4. We raise our hands to speak.

5. We keep our place neat and clean.

Peraturan pertama "We respect God and others" peraturan ini bertujuan mengingatkan murid untuk menghormati Tuhan dan sesama. Peratuan ini mengajak murid untuk bisa menghormati Tuhan sebagai otoritas tertinggi. Menghormati sesama ditujukan kepada kepala sekolah, guru, karyawan, staff, tenaga pendidik, teman sebaya, dan orangtua. Kegiatan yang mengajak murid menghormati Tuhan dapat dilihat dari adanya Morning Devotion atau devosi pagi di tiap kelas. Kegiatan devosi pagi meliputi pembacaan Alkitab, renungan singkat, pujian, dan doa.

Tujuan dari adanya devosi pagi ini untuk membantu murid mengenal Tuhan sebagai Juruselamat melalui Firman Tuhan yang tertulis dalam Alkitab. "Pemahaman yang kita berikan juga sih setiap pagi kan kita juga ada morning devotion itu kita juga tekankan terus bahwa Tuhan itu baik loh kita tuh di sini ngga sendiri loh, dengan pemahamanpemahaman seperti itu pengenalan akan Tuhan juga saya rasa itu juga salah satu faktor penting dalam pembentukkan mereka dan pertumbuhan mereka seperti itu sih" (Bunga, personal communication, October 
27, 2020). Bentuk murid menghormati sesama dilakukan guru kelas satu dalam mengajak murid untuk menjadi sahabat bagi semua. Dalam realita ada murid yang lebih suka berbicara, ada murid yang malu untuk berbicara dan tidak memiliki teman bermain. Guru meminta murid untuk menghormati kekurangan teman, dan menolong teman untuk bisa bermain bersama. "kita (guru) ajak temannya (murid) yang dalam tanda petik cerewet suka ngomong apa tu, dipanggil

Guru: "itu ajaken main"

Murid: "ndamau"

Guru: "ajak aja nggapapa"

haha akhirnya kan berani ajak-ajak. Awalnya yang malu-malu akhirnya berteman juga sih. Gitu" (Informan, personal communication, October 28, 2020).

Dalam peraturan ini, guru membiasakan murid untuk serius saat melakukan morning devotion tidak bermain sendiri atau bercanda. Guru menjelaskan pada murid, dengan mentaati guru merupakan bentuk menghormati Tuhan. Penerapan peraturan ini dilakukan dalam setiap saat, seperti pada saat pembelajaran, belajar dalam kelompok, mendengarkan teman presentasi, istirahat, bermain, dan mengerjakan tugas mandiri, dan lain-lain.

Terdapat contoh kasus berikut, saat murid sedang presentasi, ada murid " $A$ " yang berpendapat, namun murid "B" menertawakan pendapat tersebut. Guru langsung mengingatkan murid untuk tidak menertawakan pendapat yang diberikan teman lain ketika menjawab pertanyaan. Guru memberikan penjelasan kalau menertawakan jawaban teman yang kurang tepat, tanda kita tidak menghargai dan menghormati pendapat teman kita.

Berdasarkan teori perkembangan sosial dan emosional anak usia 6 hingga 7 tahun, murid kelas satu dalam tahap membangun relasi dengan teman seusianya. Dalam usia ini teman memiliki pengaruh yang besar dan membekas dalam benak mereka (Shihab, 2017). Dengan demikian peraturan "we respect God and Others" sesuai dan penting diterapkan untuk menekankan bagaimana menjadi teman baik. Guru menjelaskan teman baik itu seperti Tuhan Yesus, memiliki hati yang penuh belas kasih kepada sesama dan suka menolong.

Peraturan kedua "We listen to our teachers attentively" bertujuan mengajak murid mendengarkan dan fokus memperhatikan guru. Guru menjelaskan bahwa sebagai murid, perlu memiliki sikap yang penuh perhatian terhadap guru. "guru dapat menencourage anaknya untuk dapat belajar dengan fokus, dengan disiplin" (Bunga, personal communication, October 27, 2020). Guru menjelaskan pada murid bahwa dengan memiliiki sikap fokus, murid bisa mendapatkan pembelajaran berharga bagi dirinya dan sekitarnya.

Dalam penerapan peraturan ini, terdapat banyak karakter murid yang berbeda-beda. Terdapat murid yang sudah bisa taat dan ada yang perlu dibantu guru agar bisa taat. Ketika didapati murid yang belum bisa fokus memperhatikan pembelajaran, guru akan menghitung mundur dari angka 5 untuk memberi tanda pada murid untuk kembali attentive. Murid sudah terbiasa dengan guru yang mengingatkan dengan cara itu, murid akan langsung memperhatikan dan mengingatkan teman yang belum attentive.

Terdapat cara lain yang digunakan guru untuk mendisiplinkan murid. Strategi "Lines" strategi ini dapat dilihat pada gambar 4.3 yang telah dimuat pada lampiran. Strategi "Lines" atau penggambaran garis ini merupakan strategi yang diberikan guru agar murid konsisten mentaati peraturan. "kelas 1-2 punya 20 tuh, jadi ehh kelas 3-4 punyanya 15 , kelas 5-6, 
10 jadi sama cuman standartnya yang kita bedakan seperti itu" (Bunga, personal communication, October 27, 2020). Tujuan dari strategi ini adalah mempertahankan 20 garis. Cara menggunakan strategi ini, guru akan menggambar garis lurus sebanyak 20 untuk kelas satu. Jika didapati murid yang melanggar peraturan, guru akan menghapus garis.

Guru memiliki cara lain untuk mendapatkan perhatian dari murid. Salah satu cara adalah dengan memberikan strategi menggambar garis sebelum pembelajaran dimulai. Guru akan menggambar garis dengan jumlah 20 garis untuk kelas satu. Tujuan strategi ini untuk mendorong murid fokus mengikuti pembelajaran. Hasil dari strategi pemberian garis ini memberi penghargaan pada kelas di akhir bulan. Semakin banyak garis yang ada semakin tinggi peluang murid mendapat penghargaan.

Strategi ini mengajak murid untuk menjaga sikap disiplin di mana guru akan menghapus satu garis bila ada satu murid yang melanggar peraturan. Perilaku yang terbentuk pada murid adalah sikap disiplin mentaati peraturan atau kesepakatan yang ada. Murid akan fokus mengikuti pembelajaran dan mengingatkan teman lain untuk disiplin agar garis tidak dihapus.

Peraturan nomor tiga "We use soft voice", guru mengajarkan pada murid berkomunikasi dengan suara yang lembut. Guru memberi contoh menggunakan suara yang lembut saat berbicara. Suara lembut disini memiliki tujuan agar murid tidak berbicara dengan berteriak pada guru, tenaga pendidik, dan temantemannya. Peraturan ini didukung dengan tingkatan suara yang juga dipajang di dalam kelas. "Ada use soft voice, ada volume satu, anak-anak itu kalo waktunya test, volume suaranya satu, nanti ada gambar suaranya dua itu kalo menjawab itu lebih keras suaranya gitu. Ada silent voice, gitu ya" (Informan, personal communication, October 28, 2020). Guru membiasakan murid untuk berbicara dengan menyesuaikan kondisi yang terjadi. Contohnya ketika sedang berbicara kepada guru, murid tidak perlu menggunakan suara yang keras dan cenderung berteriak. Contoh lain ketika sedang belajar dalam kelompok, murid tidak perlu berteriak untuk menyampaikan pendapat.

Selanjutnya terdapat peraturan voice levels yang berisi tingkat volume suara yang perlu diperhatikan oleh murid. Terdapat 5 tingkatan suara, angka $0=$ silent; $1=$ whisper; 2 = teamwork; 3 = normal; $4=$ presentation; $5=$ too loud. Tujuan penerapan tingkatan suara untuk menjaga kelas dalam kondisi yang kondusif. Upaya guru menjaga ketertiban kelas dengan menerapkan peraturan tingkatan suara. Guru menggunakan tingkatan volume suara ini untuk memberi pemahaman pada murid untuk mampu bersikap sesuai dengan kondisi yang ada.

Angka 0 "silent" didefinisikan tidak ada suara. Tingkat ini digunakan guru ketika murid sedang melakukan pembelajaran mandiri. Guru mengingatkan murid menggunakan isyarat tangan mengepal merujuk pada tingkat 0 "silent" tidak ada suara. Guru menggunakan tingkatan 0 untuk menunjukkan kelas perlu dalam suasana tenang.

Angka 1 "whisper", murid diizinkan untuk berbisik. Guru menggunakan tingkatan ini ketika memasuki waktu membaca bersama di kelas. Murid diajak untuk taat pada instruksi yang diberikan guru untuk tenang saat membaca. Guru memahami kebutuhan murid kelas satu yang membaca sambil bersuara. Guru memberi instruksi "voice level 1" agar murid tetap bisa berkonsentrasi dan tidak mengganggu teman lain.

Angka 2 "team work", murid bisa bercakapcakap menggunakan suara yang pelan. Guru 
memberikan instruksi "voice level 2" ketika murid sedang berdiskusi dalam pasangan atau kelompok. Hal ini memberi pengertian kepada murid bahwa pembicaraan dalam kelompok adalah miliknya, dan tidak perlu diketahui kelompok lain.

Angka 3 "normal" digunakan murid ketika suasana pembelajaran sedang santai. Guru memberi instruksi angka 3 ketika sedang berlangsung tanya jawab. Ketika guru sedang mengajak murid berbicara juga murid berbicara dalam tingkat suara nomor 3.

Angka 4 "presentation" digunakan ketika murid sedang mempresentasikan hasil kerja dan hasil diskusi. Dalam tingkat ini guru meminta murid berbicara dengan tegas dan jelas agar teman-teman yang lain dapat mengerti apa yang dipresentasikan. Guru memberikan "voice level 2 / whisper" bagi murid yang mendengarkan.

Angka 5 "too loud" Dalam tingkat suara ini menunjukkan murid terlalu berisik. Guru akan mengangkat lima jari dan melakukan hitung mundur untuk mengembalikan situasi kelas yang kondusif. Guru menghitung mundur, seraya memuji murid yang sudah duduk dengan tertib. Guru memuji murid yang disiplin akan menyadarkan murid lain yang belum mendengar instruksi. Dalam hitungan lima kelas dapat kembali kondusif dan guru tidak melakukan perbuatan yang kasar.

Peraturan nomor empat "we raise our hands to speak" bertujuan untuk mengajarkan murid menunggu giliran dengan tertib. "Kita juga saling mengingatkan kalo ada yang lupa peraturannya salah satunya kan raise hand before to speak ya, kalau anak-anak mau keluar dari mejanya itu raise hand dulu apa yang mau dilakukan, mau tanya, mau apa, ndak saling ngobrol sendiri gitu”
(Informan, personal communication, October 28, 2020). Guru akan memilih murid yang mengangkat tangan tanpa berbicara sesuai dengan peraturan yang berlaku. Guru menerapkan peraturan ini untuk membentuk lingkungan kelas yang adil bagi seluruh murid. Guru mengenal berbagai karakter dalam kelas, terdapat murid yang aktif dan yang kurang aktif. Peraturan ini membentuk pola pikir murid untuk bergantian dan melatih rasa percaya diri murid akan pendapatnya. Guru menerapkan ini agar murid memiliki pemikiran bahwa tidak semua bisa sesuai dengan kemauannya, melainkan terdapat peraturan yang perlu ditaati.

Peraturan nomor lima "we keep our place neat and clean" bertujuan untuk mengajak murid untuk memiliki tanggung jawab akan lingkungan. Guru selalu mengingatkan selesai mengadakan pembuatan prakarya, mengerjakan modul, istirahat, dan saat pulang untuk memeriksa kebersihan sekitar tempat duduk murid. Guru mengingatkan untuk menjaga kebersihan untuk kebaikan dan kesehatan murid sendiri. Cara guru mengajak murid dengan menyediakan tempat sampah di dalam kelas. Guru memberikan gambaran melalui cerita pada murid bila lingkungan kotor karena tidak taat menjaga kebersihan murid yang akan dirugikan.

Peraturan "Hi 5" dilaksanakan oleh guru secara konsisten. Guru menekankan pentingnya konsistensi menerapkan disiplin pada murid terutama kelas satu. Guru dapat mengganti istilah peraturan dengan kesepakatan. "peraturan itu kita sebutnya agreement waktu itu. Jadi kita susun-susun bersama agreements apa aja. Jadi yang kita sampaikan ini agreements loh ya berarti bukan dari satu sisi aja kan, bukan dari sisi guru aja, tapi dari murid juga memahami hal itu dan juga menyepakatinya gitu kan" (Bunga, personal communication, October 27, 2020). Di tengah jalan jika terdapat murid yang mulai tidak disiplin, guru mengingatkan peraturan dan kesepakatan bersama dan guru melakukan percakapan dengan murid tersebut. 
Peraturan yang dibuat oleh guru untuk menolong murid dapat konsisten mentaati peraturan. Peraturan yang ditetapkan untuk kebaikan murid dalam jangka waktu dekat, dan bekal karakter positif dalam masa mendatang. Seperti yang dikatakan oleh Ms Bunga "guru dapat men-encourage anaknya untuk dapat belajar dengan fokus, dengan disiplin, ada yang dengan pemberian bintang misalnya" (Bunga, personal communication, October 27, 2020). Guru perlu memiliki kreatifitas dalam mengupayakan konsistensi murid mentaati peraturan. Tidak hanya konsisten mentaati peraturan, guru juga perlu mengemas peraturan agar murid dapat memahami makna dibalik peraturan dan bukan takut akan hukuman yang diberikan bila mereka melanggar.

Upaya guru mendisiplinkan murid secara positif dalam pembelajaran, juga dilakukan untuk memotivasi murid untuk lebih aktif. Guru mengolah secara positif dan kreatifit pada sistem mendisiplinkan murid, dengan menggunakan penguatan "reward" untuk menolong murid dan mengapresiasi proses belajar murid. Dalam kelas I-A guru menegakkan peraturan dengan cara yang mendorong murid selalu ingat peraturan "Ms Ria inget dulu yang saya suka gambar lines itu yang di papan" (Bunga, personal communication, October 27, 2020).

"Nanti di setiap akhir tema itu akan diperhitungkan yang dapet 10 nanti bisa dapet reward apa, yang dapet lebih dari berapa nanti bisa dapet plus poin juga untuk projectnya seperti itu sih cara kita men-encourage anakanak" (Bunga, personal communication, October 27, 2020). Berdasarkan wawancara dengan guru Bahasa Inggris, beliau menyampaikan mengajar murid kelas satu SD memiliki tantangan tersendiri, jika peraturan yang diberikan kurang menyenangkan murid akan enggan mengikuti dan mudah bosan.

\subsection{Penerapan Disiplin Positif dengan Pemberian Konsekuensi Logis dan Alami}

Penerapan disiplin positif mendukung guru membentuk karakter yang benar bagi murid. Murid yang melakukan kesalahan atau menunjukkan sikap tidak taat perlu pemahaman mana sikap yang benar dan bagaimana seharusnya sikap yang benar. Karena itu, guru memberikan konsekuensi sebagai pengertian bagi murid akan hal yang perlu diperbaiki.

Sebagai contoh, murid menumpahkan air di sebelah mejanya, konsekuensi yang diberikan guru adalah meminta murid memanggil petugas kebersihan untuk membantu membersihkan air yang tumpah. Contoh selanjutnya, murid "A" yang selesai belajar tidak segera membereskan meja. Murid melanggar peraturan kelas mengenai "we keep our place neat and clean". Guru memberi waktu murid membereskan. Murid "A" membereskan meja sendiri di saat teman lain sudah selesai, murid "A" akan merasakan akibatnya bila tidak segera membereskan, akan merugikan orang lain. "Sejak anak-anak masih kecil ini, saya habis belajar ngga boleh nih meja berantakan, jadi saya harus merapikan, mainan harus saya rapikan. Kebiasaan ini kalau dibangun terus akan terbawa selamanya. Tapi kalo sejak kecil sudah ngga tanggung jawab, ngerjakan tugas kadang nda dikerjakan, dampaknya itu sudah akan buruk" (Informan, personal communication, October 28, 2020). Guru menjelaskan bila murid tidak bertanggung jawab, konsekuensinya harus ditanggung sendiri dan bisa memberi dampak buruk bagi orang lain.

Terdapat kasus lain mengenai murid yang senang berbincang sendiri dengan teman sebangku saat teman lain sedang presentasi. Murid melanggar peraturan mengenai "we respect God and others". Guru memberikan konsekuensi logis dengan menegur secara lisan sebanyak dua kali belum menyadarkan kesalahan murid, maka guru meminta murid 
tersebut untuk membawa kursinya dan duduk di sebelah guru. Perbuatan ini mampu mengurangi sikap tidak disiplin murid dan murid bisa belajar menghargai teman yang sedang presentasi.

Kasus lain didapati murid melanggar peraturan dengan tidak mendengarkan guru mengajar. Guru menegur dengan mengingatkan peraturan "we listen to our teachers attentively" untuk kembali taat pada peraturan. Namun peringatan lisan belum bisa menyadarkan kesalahan murid, guru memberi kebebasan murid untuk membaca buku di pojok membaca yang telah tersedia di kelas pada waktu istirahat. "Jadi di kursinya (murid) boleh baca, hanya mengurangi kesenangan untuk bermain bersama teman-teman, tapi tetap dia (murid) ngga rugi. kita (guru) bisa damping dan kasi tahu bahwa perbuatanmu nda baik ya, lain kali jangan seperti ini" (Informan., personal communication, October 28, 2020). Guru menekankan bahwa pemberian time-out pada murid tidak perlu menggunakan kekerasan yang menyakiti secara fisik maupun psikis.

Konsekuensi selanjutnya merupakan konsekuensi alami. Sebagai contoh kelas dalam keadaan tidak kondusif saat berdiskusi dalam kelompok, murid akan merasa terganggu karena teman yang banyak bicara. Konsekuensi alami yang terjadi adalah perdebatan atau konflik. Guru mulai menghitung mundur untuk mengkondusifkan kelas. Jika tetap ada murid yang tetap berbicara sendiri, guru akan mengajak bicara secara personal. "Salah satu cara efektif adalah kita perlu cari tahu kan, mungkin memang karena anak-anak kan datang dari latar belakang yang berbeda, latar keluarga yang berbeda, lingkungan yang berbeda, seperti itu" (Bunga., personal communication, October 27, 2020). Guru menekankan bahwa salah satu cara yang efektif memberikan konsekuensi adalah pendekatan secara pribadi.

Kasus lain, konsekuensi alami yang terjadi ketika murid tidak membereskan mainan setelah digunakan, mereka terluka jika tidak sengaja menginjaknya. "Misalnya kaya gini "cobak kalian bayangkan deh kalo kalian habis main ga diberesin setelah recess, trus waktu pelajaran gimana?" Itu nanti jawabannya juga akan datang dari mereka sendiri "nanti keinjek Ms mainannya sakit, nanti belajarnya ndak nyaman." Lho berarti kan apa mereka mengetahui hal itu kan, kita membantu menyadarkan mereka akan pentingnya hal-hal itu untuk diri mereka sendiri" (Bunga, personal communication, October 27, 2020). Guru menjadi media dan pengingat bagi murid khususnya kelas satu untuk membayangkan resiko dari perbuatan mereka.

Dalam pemberian konsekuensi perlu disesuaikan dengan karakter setiap murid. Guru perlu mengenal murid satu persatu dengan melihat latar belakang murid, kebiasaan saat murid di kelas, dan pada waktu istirahat. Menurut guru, penerapan yang dilakukan pada murid A belum tentu efektif dan tepat dengan kebutuhan murid. Murid A diberikan konsekuensi logis sudah bisa memahami sebab-akibat dari perbuatannya. Pada murid B belum tentu konsekuensi logis dapat diterima. Pemberian konsekuensi yang sesuai dengan kebutuhan murid bertujuan menolong murid bisa belajar dan semakin memiliki sikap disiplin.

Konsekuensi merupakan kesempatan belajar bagi masing-masing murid. Konsekuensi bisa diberikan secara menyeluruh, namun lebih efektif bila diberikan sesuai dengan kebutuhan individu murid. Kesepakatan konsekuensi yang dibuat oleh guru yang disetujui oleh murid adalah pemberlakuan teguran, percakapan dengan guru secara pribadi, pemberian time-out, dan jika dirasa pelanggaran berat, orangtua akan dipanggil oleh guru. Hingga saat ini guru belum pernah memanggil orangtua perihal 
pelanggaran yang dilakukan murid.

Guru tidak hanya memberi dan mengajak murid, namun guru juga melakukan peraturan tersebut. "Kalau kita disiplin dengan sendirinya kita nih berhubungan dengan tanggung jawab. Ngasi contoh aja kita disiplin, anak-anak harus disiplin. Anak-anak tuh kalu misalnya datang sekolah tepat waktu ya, tepat waktu. Berarti kita tidak hanya sekedar "kamu harus disiplin, harus datang tepat waktu" (Informan., personal communication, October 28, 2020). Dengan demikian, guru menanamkan sikap bertanggung jawab pada diri sendiri pada murid. Akibatnya murid dapat mengerti pentingnya dan merasakan sendiri manfaat datang tepat waktu.

\subsection{Penerapan Disiplin Positif dengan Menggunakan Ketegasan}

Guru menerapkan disiplin positif dengan menggunakan ketegasan, dapat dilihat pada contoh berikut. "coba kalian (murid) bayangkan deh kalo kalian (murid) habis main ga diberesin setelah recess, trus waktu pelajaran gimana?" (Bunga., personal communication, October 27, 2020). Guru mencoba memberikan gambaran pada murid apabila murid tidak mau mentaati peraturan. Guru tegas memberitahu bahwa membersihkan lingkungan itu penting dan lingkungan yang tidak bersih dapat melukai diri sendiri. Guru tegas meminta murid membereskan lingkunganya berdasarkan peraturan yang telah dibuat "we keep our place clean and neat".

Contoh lain jika guru marah, yang terjadi guru menyalahkan, menyuruh, dan tidak mengajak murid berpikir akibat yang terjadi. Contoh ungkapan yang terjadi bila guru marah seperti berikut "ayo jangan males bersihin gini aja kok males, besar mau jadi apa" ungkapan tersebut mungkin orang dengar sewaktu masih kecil. Amarah bukan merupakan bagian dari disiplin positif. Amarah tidak fokus pada pelajaran bagi murid, namun hanya ungkapan perasaan emosi dan tidak memiliki tujuan mendidik.

Suatu hari ada murid terlambat masuk kelas. Murid lain sudah duduk dan siap mengikuti devosi pagi, Guru menyapa murid yang terlambat dan mempersilahkan murid tersebut untuk duduk. Murid tersebut duduk dan terlihat menundukkan kepala. Guru memanggil murid yang terlambat setelah devosi selesai. Guru mengajak bicara secara pribadi di meja guru. "Kenapa A (nama murid) kok terlambat? Kalo A terlambat datang, A bisa tertinggal pelajaran" (Informan., personal communication, October 28, 2020). Guru tegas memberitahu bahwa penting untuk bisa datang tepat waktu. Guru menjelaskan bahwa dengan mengikuti devosi pagi penting dan bagian dari kegiatan yang harus ditaati.

Guru memberikan ketegasan disertai dengan alasan. Pentingnya menyertakan pengertian, membuat murid berpikir secara logis. Ketegasan yang diberikan tidak memberi kesan murid salah, dan guru selalu benar. Percakapan guru kepada murid berkaitan dengan alasan mengapa perlu mentaati peraturan. "kita (guru) harus kasi tahu juga apa sih manfaatnya misal kita datang tepat waktu, ya kamu (murid) tidak akan tertinggal, seperti itu). (Informan., personal communication, October 28, 2020).

Guru memberi ketegasan kepada murid didukung dengan memberi pengertian kepada orangtua. Informasi dan peraturan yang telah ditetapkan, perlu diperhatikan murid dan orangtua. Guru menekankan bahwa peraturan dibuat untuk kebaikan murid. Komunikasi yang dilakukan guru pada orangtua, diharapkan orangtua mengerti dan mendukung proses pembentukan karakter disiplin bagi murid. Guru melakukan proses penerapan disiplin positif ini dengan pengertian bahwa murid tidak bisa ditegur di depan kelas dan di depan teman-temannya. Guru 
mengharapkan orangtua dapat menjadi pendukung utama bagi pertumbuhan karakter disiplin anaknya.

Penerapan ketegasan yang dilakukan oleh guru dilakukan dengan penerimaan akan kondisi murid terlebih dahulu. Guru memahami dan menghargai alasan dibalik perilaku tidak disiplin murid. "Pelan-pelan kita cari tau kenapa apa sih yang menyebabkan anak ini ngga bisa fokus atau ngga mau mengerjakan sesuatu biasanya akhirnya terkuak. Ada yang misalnya karena kemarin tidurnya kemaleman, atau karena habis dimarahin orangtuanya, apa, nah dengan itu kita bisa memberikan pengertian kepada mereka baru itu nanti mereka bisa berubah. Ya mungkin akan terulang kembali tapi ya itu sih, pendekatan terus lamalama mereka akan terbiasa gitu" (Bunga, personal communication, October 27, 2020). Pemahaman ini dilakukan mengingat bahwa tidak semua murid bisa menerima langsung sikap tegas. Perlu diingat bahwa menerapkan ketegasan pasti ada tujuan. Tujuannya adalah membangun sikap disiplin murid, perlu didampingi pengenalan akan karakteristik murid. Dengan begitu ketegasan dapat diterima murid sebagai hal penting demi kebaikan diri murid.

Latar belakang murid yang beragam menjadi faktor keberhasilan penerapan ketegasan. Murid yang memiliki orangtua yang tidak pernah menegur, tidak bisa menerima sikap tegas guru begitu saja. Murid yang terbiasa ditegur oleh orangtua di rumah, mampu menerima sikap tegas guru dan menangkap maksud guru dengan tepat. Guru memberikan ketegasan dan tetap menghormati, menghargai usaha murid untuk belajar dari kesalahan yang dilakukan.

\subsection{Penerapan Disiplin Positif dengan Keikutsertaan Orangtua}

Penerapan disiplin positif didukung dengan keikutsertaan orangtua. Kegiatan yang dilakukan antara lain adanya pertemuan dengan orang tua pada awal tahun pembelajaran, pembagian rapor, pemberitahuan informasi mengenai bimbingan pribadi murid, "setiap awal tahun pembelajaran pasti ada pertemuan orangtua jadi khususnya kelas satu ya, itu judulnya parents teacher conference terutama untuk wali kelas" (Bunga, personal communication, October 27, 2020). Guru menjelaskan kegiatan yang akan dilakukan, peraturan dan ketentuan yang berlaku, dan informasi tambahan seiring berjalannya waktu. Kesepakatan ini berisikan peraturan yang perlu ditaati dan ada konsekuensi yang perlu dilakukan murid bila melanggar.

Guru akan menyampaikan kondisi murid baik dalam aspek kognitif, sikap yang perlu ditingkatkan atau perlu mendapat bimbingan khusus. Guru menyampaikan perkembangan, kendala, dan target yang perlu dicapai murid kepada orangtua. "Kalo kami merasa anak-anak ini sudah disiplin, sudah bagus ya, kami hanya waktu terima rapot kami beritahukan kalau anak ini memang begitu. Kalau anak itu tidak disiplin dan sudah berkali-kali dan kita tidak mengatasi, baru kita ajak kerjasama dengan orangtua. Kita panggil orangtua baru kita beritahu pentingnya disiplin ini seperti apa" (Informan., personal communication, October 28, 2020). Hal ini dilakukan sebagai wujud keikutsertaan orangtua dalam memantau perkembangan anak.

Tujuan mengikutsertakan orangtua untuk meningkatkan relasi murid dengan orangtua. Tujuan selanjutnya agar orangtua juga menerapkan hal yang sama di rumah. Khusus pada murid kelas satu memerlukan penanganan lebih, guru perlu mengkomunikasikan pada orangtua mengenai penerapan disiplin yang diterima murid di sekolah. Guru menyampaikan bahwa murid kelas satu sangat mudah meniru perilaku orang yang ada di 
sekitarnya. Guru juga menekankan pada orangtua bahwa pentingnya konsistensi dan peran orangtua sebagai teladan bagi anak.

Penanaman karakter dan proses belajar tidak bisa lepas dari dukungan orang tua. Jika didapati murid yang tidak taat dan guru sudah memberikan konsekuensi namun tidak terjadi perubahan, guru perlu kerjasama orangtua. Peneliti melakukan wawancara dan guru berkata, "Kita beritahu, kalo misalnya sekali dua kali diberitahu ngga bisa, biasanya kita ngga ada punishment. Kita ada namanya timeout gitu, tapi time-outnya bukan yang merugikan anak" (Informan, personal communication, October 28, 2020)

\subsection{Penerapan Disiplin Positif dengan Dorongan Guru akan Kemampuan Diri Murid}

Guru menyadari sepenuhnya bahwa dirinya adalah panutan / teladan bagi murid. Guru memegang peran penting bagi murid dimanapun dan kapanpun. "Kita (guru) harus memberikan contoh yang baik untuk mereka (murid) apalagi kelas satu ya, masih tinggi-tingginya meniru" (Bunga, personal communication, October 27, 2020). Tidak dipungkiri, guru bisa merasa lelah dan merasa sedih atau tidak bersemangat. Ekspresi, ucapan, dan perilaku dapat dilihat dan ditiru oleh murid, jika guru memiliki pergumulan dan terbawa ke dalam kelas, akan berdampak buruk bagi suasana pembelajaran. Sikap taat pada peraturan perlu guru lakukan terlebih dahulu agar murid mampu meniru sikap taat guru.

Dorongan dapat berupa penguatan dengan pemberian bintang, beads, dan lain-lain. Dorongan tersebut dapat diperoleh ketika murid dapat mengikuti peraturan yang ada.
Tujuan pemberian dorongan agar murid mentaati peraturan untuk membantu dirinya menjadi pribadi yang lebih baik bukan karena hal lain. Pada kelas satu perlu cara yang kreatif agar murid mampu termotivasi, terdorong dari dalam diri untuk disiplin pada peraturan.

Pemberian dorongan oleh guru pada murid paling sering berupa dukungan secara verbal. Ketika murid mengalami lelah belajar bahkan menyerah dalam belajar, guru memberi dorongan seperti ini, "Kenapa kamu merasa lemah? "Tuhan itu sudah memberikan kita kepandaian, memberikan kita hikmat untuk belajar, dari kecil kan diberkati sampe udah di kelas satu lho sekarang. Pasti bisa kok." (Bunga, personal communication, October 27, 2020). Dorongan berupa apresiasi secara verbal ini dapat menolong murid yang sedang memiliki pergumulan tentang rasa pecaya pada Tuhan dan berkat Tuhan terhadap dirinya.

Pemberian dorongan dilakukan guru dengan memberikan kebiasaan bagi murid. Guru memberi kesepakatan apabila memasuki kelas Bahasa Inggris, murid harus berkomunikasi menggunakan Bahasa Inggris. "Kebutuhannya apa aja salah satunya contohnya misalnya, oh ini kelas Inggris nih misalnya Ms Bunga masuk atau Ms atau Mr yang lain masuk gitu, oh berarti mereka biasanya udah pasti langsung tuh switch ngomongnya langsung pake Bahasa Inggris. Lha ya itu agreement-agreements yang kita sepakati." (Bunga, personal communication, October 27, 2020). Guru melakukan dorongan pada murid untuk lebih percaya dengan kemampuan berbahasa Inggris.

Hal tersebut juga menjadi dampak positif bagi guru yang belum fasih berkomunikasi dengan Bahasa Inggris, dengan kata lain mendorong guru lebih aktif berkomunikasi menggunakan Bahasa Inggris. Pembiasaan dan kesepakatan ini merupakan dorongan bagi murid dalam meningkatkan kemampuan Bahasa Inggris. Memiliki kemampuan Bahasa Inggris yang 
baik tidak bisa instan, sehingga penerapan peraturan dan kemampuan dapat berjalan beriringan.

Guru perlu memahami perbedaan dalam memberikan dorongan bagi murid. Berdasarkan observasi dan wawancara, peneliti menyadari bahwa guru tidak banyak memberikan pujian pada murid. Guru memberikan pernyataan, "Kamu lebih hebat lagi kalau kamu attentive atau apa", "kamu bisa jadi teladan bagi teman-temanmu yang lain" (Informan, personal communication, October 28, 2020). Dengan perkataan "kamu bisa menjadi teladan bagi teman-temanmu yang lain", guru mendorong murid untuk bisa tetap disiplin dalam mentaati peraturan. Murid memiliki pola pikir yang baru ketika dia disiplin, akan memberikan pengaruh positif bagi teman lain.

Guru yang memiliki relasi baik dengan murid dapat memotivasi murid. Guru dengan relasi baik, akan lebih diterima oleh murid. Murid merasa nyaman dan aman untuk menceritakan apapun tentang dirinya bahkan mengenai kesulitan murid memiliki sikap disiplin. Guru dapat mengarahkan pola pikir murid untuk melihat suatu kesalahan sebagai proses untuk menjadi yang lebih baik. Cara guru memotivasi murid dengan senantiasa mengingatkan peraturan, manfaat dari taat pada peraturan, dan dampaknya.

Kunci dalam proses memotivasi murid untuk bisa memiliki sikap disiplin dengan mengaitkan peraturan dengan kehidupan murid. Guru yang mengaitkan sikap disiplin pada murid dapat membuat murid mampu mengevaluasi perilaku yang dilakukan apakah sudah benar atau belum. Kerinduan guru melihat murid memiliki sikap disiplin tidak lepas dari konsistensi dan perilaku yang guru lakukan.

\subsection{Integrasi Iman Kristen dalam Menerapkan Disiplin Positif}

\section{Morning Devotion}

Sekolah Dasar Kristen ' $\mathrm{X}$ ' memiliki visi untuk membangun generasi yang cemerlang dengan berdasarkan kebenaran Firman Tuhan. Sejalan dengan visi tersebut, sekolah memiliki kegiatan Morning Devosion atau renungan pagi. Kegiatan ini dilakukan untuk seluruh jenjang kelas dari kelas satu hingga kelas enam. Cara penyampaian Firman Tuhan dikemas dengan cara yang berbeda berdasarkan jenjang kelas. Devosi untuk kelas satu dan dua dilakukan oleh guru kelas. Devosi untuk kelas tiga hingga enam disampaikan melalui radio sekolah.

Guru mengawali kelas dengan mengajak murid melakukan Morning Devotion. Dalam devosi pagi, guru menyampaikan renungan Firman Tuhan dan contoh yang relevan dalam kehidupan sehari-hari murid kelas satu SD. Guru yang mengawali hari dengan Firman Tuhan, mengajarkan murid untuk menjadikan Allah sebagai dasar dalam kehidupan. Anak-anak memiliki natur dosa, sehingga perlu adanya tuntunan dari orang tua dan guru selaku orang tua di sekolah untuk menuntun ke arah yang benar (Hendra, 2015). Alkitab merupakan Firman Tuhan yang tertulis berisikan kebenaran yang teruji secara historis dan relevan bagi seluruh aspek kehidupan manusia (New Hope International, 2015).

Dalam mengingatkan peraturan kepada murid, guru memberi pengertian akan kasih Tuhan yang menyertai kita selama ini. Guru menegur murid yang tidak disiplin secara pribadi. Guru menegur secara pribadi seperti yang Tuhan Yesus ajarkan dalam kitab Matius 18:15 yang meminta kita menegur dengan empat mata. Guru perlu memiliki kemampuan memotivasi diri menjadi lebih baik, agar murid kelas satu dapat melihat proses ketika sedang sedih, Tuhan beri kekuatan dan diri sendiri perlu berjuang melewati pergumulan dengan Tuhan.

Devosi yang dilakukan pada kelas satu menggunakan bahasa yang sederhana menggunakan buku renungan yang 
disediakan oleh sekolah. Devosi dilakukan dengan mengawali dalam doa, pembacaan Alkitab, renungan dan menutup dengan pujian atau doa. Guru yang memberikan devosi terlebih dahulu menuliskan di papan bacaan Firman Tuhan. Guru mengajak seluruh murid untuk membaca secara bersama-sama walau ada yang terlalu capat dan ada yang tertinggal.

Teori mengemukakan bahwa menerapkan dasar kebenaran sejak dini suatu keharusan untuk diterapkan dalam perkembangan murid kelas satu SD. Banyak yang beranggapan bahwa anak yang masih kecil masih belum tahu apa-apa. Hal itu salah dalam sudut pandang Kristen, justru karena anak-anak belum tahu mengenai kebenaran, guru dan orangtua yang ambil peran menolong mereka dengan cara yang sesuai.

Setelah melakukan pembacaan Alkitab, guru menjelaskan cerita yang berkaitan dengan bacaan Alkitab. Dalam hal ini, guru menjelaskan pada murid dengan perumpamaan yang dekat dengan kehidupan murid kelas satu SD. Guru bertanya apakah murid memahami pesan Tuhan pagi ini dengan pertanyaan seputar nama tokoh, perbuatan baik dan perbuatan buruk, fokus kita dalam mengerjakan sesuatu. Dengan percakapan demikian, guru dapat menolong murid untuk mengenal Tuhan melalui cerita Alkitab dan perumpamaan yang diberikan. Berdasarkan teori perkembangan kognitif, murid kelas satu dapat mengobservasi pengalaman pribadi dan mengkaitkan dengan perumpamaan yang disampaikan guru (Shihab, 2017).

Murid-murid terlihat bersemangat ketika guru menanyakan hal yang dekat dengan kehidupan mereka. Murid yang mendengar perumpamaan yang diberikan, tiba-tiba mengangkat tangan dan bercerita hal lain yang ia alami dan berkaitan dengan renungan saat itu. Guru mendengarkan dan menanggapi dengan baik. Ketika ada satu murid yang ingin bercerita, murid lain tergerak untuk menyampaikan pengalamannya masingmasing. Dalam kondisi seperti ini, sering kali kelas menjadi tidak kondusif, murid mulai ribut karena ingin menyampaikan cerita.

Meskipun guru melihat antusiasme murid yang ingin berbagi kisah, guru tetap dengan tegas mengingatkan tentang peraturan yang berlaku. Peraturan yang diingatkan seperti "we respect God and others", dan "raise hand before speak". Guru mulai menghitung mundur dari lima hingga 1 dan kelas menjadi kondusif. Setelah kondusif guru menyampaikan bahwa bersyukur banyak murid yang mengalami kasih Tuhan. Dalam situasi ini guru tetap konsisten menerapkan peraturan dan menolong murid untuk konsisten dalam mentaati peraturan.

Hari berikutnya, guru mengawali dengan menanyakan pesan pada devosi pagi hari sebelumnya. Didapati murid yang mengangkat tangan dan menceritakan pesan beserta nama tokoh pada devosi hari sebelumnya. Guru menyampaikan rasa syukur karena pesan hari kemarin tidak lalu begitu saja dari murid-murid. Sebagai contoh pada devosi pagi tanggal 3 September 2019 guru menyampaikan cerita tentang Yunus. Murid-murid sangat fokus mendengarkan guru.

Saat memberikan pertanyaan seperti apa yang dilakukan Yunus, mengapa Yunus berbuat demikian, murid-murid dapat menjawab dengan benar. Guru juga menyampaikan kisah nyata tindakan tidak taat itu seperti apa. Guru menyampaikan mengapa kita bisa tidak taat itu karena perbuatan si jahat, yaitu iblis. Guru memberikan contoh kasus "kalau murid tidak attentive, siapa yang mengajak?" murid menjawab "iblis". Guru melanjutkan 
pertanyaan lain dan murid menanggapi dengan baik dan sopan sesuai dengan peraturan yang berlaku.

Integrasi iman Kristen yang dilakukan guru saat melakukan proses belajar mengajar, dengan melihat kendala yang dialami murid dalam mentaati peraturan yang telah dibuat. Murid memiliki kesusahan mentaati peraturan yang mana, guru perlu mengamati dan mencari solusi akan kesulitan murid untuk taat pada peraturan. Guru perlu melakukan observasi mengenai kendala murid untuk bisa taat secara rutin. Ini berarti observasi tersebut harus dilakukan setiap saat guru berinteraksi dengan murid. Guru harus mengerti pola kebiasaan murid tertentu dalam mengikuti kegiatan pembelajaran. Seperti yang kita ketahui Tuhan menciptakan setiap anak berharga dan berbeda tiap anaknya. Terdapat murid yang aktif berbicara, berjalan, dan murid yang diam. Dari pengenalan dan penerimaan guru akan karakter tiap murid, guru telah meneladani karakter Tuhan Yesus yang mengenali dan memelihara murid-muridNya (New Hope International, 2015).

Guru setiap hari berhadapan dengan murid sehingga guru harus memiliki kepekaan akan pola perilaku murid. "Jadi biasanya kita (guru) kalo uda terbiasa lihat polah anak-anak gitu kan kita (guru) sudah paham oh, anak ini kalau lagi marah seperti ini, ada sesuatu yang buat dia (murid) bete" (Bunga, personal communication, October 28, 2020). Guru yang peka dengan perilaku dan karakter murid, akan mudah mendisiplinkan murid.

Sejalan dengan teori pendidikan Kristen, guru Kristen yang dipimpin Roh Kudus memiliki panggilan dan hidupnya diarahkan oleh kasih untuk mengasihi (New Hope International,
2015). Roh Kudus bekerja dalam hati guru Kristen untuk mengarahkan anak-anak kepada kebenaran Kristus dan hidup berpusat pada Kristus. Dalam memahami karakter setiap murid, guru dipimpin Roh Kudus untuk menemukan cara mengarahkan murid pada disiplin yang sesuai dengan ajaran Kristus.

Guru harus mampu menyesuaikan pendekatan dan teknik mendisiplinkan setiap murid. "Kita (guru) gali apa ya yang membuat anak ini seperti ini, 'Oh ternyata anak ini hanya membutuhkan perhatian, pujian yang lebih"' (Informan, personal communication, October 28, 2020). Guru yang memahami alasan murid bersikap tidak disiplin, akan membuat murid lebih mudah menerima masukan. Roh Kudus bekerja dalam guru menemukan cara yang positif tanpa amarah. Tuhan Yesus mengaruniakan hikmat pada guru agar bisa mendisiplinkan murid tanpa kekerasan.

Pentingnya integrasi iman Kristen bagi guru untuk mengenalkan murid akan Tuhan dan kehidupan dunia itu bukan dua hal yang berbeda. Integrasi dimulai dari sudut pandang guru yang benar akan Firman Tuhan (New Hope International, 2015). Guru yang mendasari hidupnya pada Tuhan akan mencerminkan karakter Allah melalui pikiran, perkataan, dan perilaku bagi murid. Seperti kisah berikut guru membagikan cerita seorang murid memahami dan mengalami kasih Tuhan. "Tuhan itu kok baik banget menciptakan kita seperti ini, sampek ada satu anak itu berbicara gini "Kenapa sih kok kita harus sayang sama diri kita sendiri?" Seperti itu and then dia jawab "Because God treated us wonderfully" (Bunga, personal communication, October 27, 2020).

Pengetahuan akan Tuhan tidak dapat dipisahkan dengan pengetahuan umum. Pengetahuan Alkitabiah menolong guru dan murid memahami aspek yang ada dalam kehidupan. Guru perlu menjelaskan bahwa Alkitab adalah dasar bagi manusia untuk menjalani kehidupan (New Hope International, 2015). Dalam menjalani 
kehidupan, murid tidak akan tersesat atau menjadi beban bagi sekitar karena Tuhan sudah menjadi dasar dalam hati dan pikirannya. Dengan kita mendasari hati dan pikiran kita dalam kebenaran Tuhan kita bisa menjalani panggilan dan menggenapi tujuan kita.

Dalam menggenapi tujuan hidup, perlu adanya disiplin dan konsistensi. Tujuan kita untuk hidup bagi Allah dan memuliakan namaNya (New Hope International, 2015). Guru yang meneladan pada Tuhan Yesus perlu disiplin dan konsisten membangun relasi denganNya. Demikian pada murid kelas satu SD perlu meneladan karakter Kristus melalui guru di sekolah. Hal tersebut cukup abstrak bagi murid kelas satu SD. Pergumulan menyederhanakan suatu hal yang abstrak perlu hikmat dari Tuhan agar tidak salah tafsir.

Dari pergumulan tersebut, sekolah memberikan pelatihan dan sharing mengenai bagaimana mengintegrasikan iman Kristen. "Itu ada training untuk mengintegrasikan iman Kristen" (Bunga, personal communication, October 27, 2020). Integrasi yang dilakukan adalah hal yang paling dekat dengan kehidupan murid. Contoh integrasi yang dilakukan mengenai cara bersyukur, mengasihi, rendah hati, dan melayani sesama.

Menerapkan disiplin dan mengintegrasikan konsep tersebut dengan Iman Kristen tidak bisa dalam waktu yang singkat. Demikian juga dengan pembentukan sikap disiplin yang berdasarkan pada Firman Tuhan tidak bisa instan. Guru pun masih mengalami proses dan pembentukan Tuhan mengenai disiplin. "Dari kelas besar ke kelas kecil gitu dari hal tersebut buat saya berefleksi sih. Wah kalo bukan pimpinan Roh Kudus juga itu kesabaran itu saya juga ga tau datangnya dari mana" (Bunga, personal communication, October 27, 2020). Dengan sikap taat dan membangun relasi dengan Tuhan secara konsisten mampu memberikan kekuatan.

Seperti Allah Bapa mendisiplinkan kita anakNya agar selalu dalam jalan yang benar, demikian juga guru. Guru senantiasa dibentuk dan diproses secara personal agar tetap taat padaNya (Hendra, 2018). Pendisiplinan yang diterima guru pada masa kecil mungkin tidak sesuai dengan prinsip kasih Allah. Guru yang menerima keselamatan dewasa ini perlu menjadikan hal tersebut sebagai pengalaman dan pengajaran pada murid. Guru yang diselamatkan oleh kasih Allah dipanggil menjadi pelopor kasih dan keadilan dalam hal mendisiplinkan murid (Sitorus, 2018).

\section{KESIMPULAN}

Menerapkan disiplin positif mengarahkan murid pada gambaran besar akan ketaatan pada Tuhan. Guru memiliki beban untuk menolong dan mengarahkan murid kepada gaya hidup yang berkenan dihadapan Allah. Memiliki tugas melayani kelas satu SD memiliki kesukaan tersendiri. Melihat tingkah laku murid yang masih perlu bantuan, ada murid yang sudah terbiasa mandiri, dan keunikan lainnya. Tantangan mengajar kelas satu SD adalah menjadi teladan Allah dan mengintegrasikan maksud dan pesan Allah dalam bahasa yang sederhana.

Dengan adanya penerapan disiplin ini diharapkan mampu mengurangi kasus kekerasan yang menggunakan dalih mendisiplinkan murid. Penerapan disiplin positif yang dilakukan di sekolah dasar Kristen ' $\mathrm{X}$ ' mampu menjadi inovasi baru dalam mendisiplinkan murid. Keunikan dalam penerapan disiplin positif ini adalah dengan mendasari kegiatan dengan Tuhan sebelum pembelajaran. Benar bahwa guru tidak bisa memprediksi apa yang akan terjadi di dalam kelas. Guru menjadi tangan kanan Allah dalam mengasihi murid dan 
Roh Kudus yang memberi hikmat bagi guru Kristen. Dalam bab ini peneliti dapat menarik beberapa kesimpulan yang akan peneliti sampaikan sebagai berikut.

Sekolah Dasar Kristen ' $X$ ' Surabaya telah menerapkan disiplin positif dengan mengintegrasikan Iman Kristen. Terbukti dari peraturan yang dibuat peneliti melihat sesuai dengan ajaran iman Kristen. Peraturan pertama dibuat dengan mengutamakan dan menghormati Tuhan Yesus diatas segalanya. Dilanjut dengan menghormati dan mengasihi sesama. Peraturan kedua merujuk pada taat pada otoritas tertinggi dalam kelas yaitu guru. Guru menerapkan peraturan dengan mengintegrasikan nilai Kristen kepada murid kelas satu sesuai dengan tahapan perkembangan kognitif, fisik, emosi, dan psikologis.

Tahapan perkembangan yang dimaksud yaitu perkembangan kognitif, guru membuat peraturan dengan kata yang sederhana dan tidak asing bagi murid. Cerita dari Alkitab yang disampaikan menggugah murid kelas satu untuk bercerita mengenai pengalaman pribadinya. Guru menyampaikan penjelasan makna kasih dan keadilan dengan penuh perasaan dan murid merespon dengan kata yang sering mereka dengar seperti "God have treat us wonderfully ya, Ms".

Pelaksanaan disiplin positif yang dilakukan menggunakan konsekuensi logis dan alami. Guru menerapkan konsekuensi pada murid yang tidak disiplin. Guru mengizinkan murid menerima konsekuensi alami sebagai kesempatan murid untuk belajar. Guru menjelaskan kembali alasan mengapa konsekuensi alami bisa terjadi kepada murid. Murid menerima masukan, nasehat, dan perhatian guru dengan lapang dada. Hal ini dapat dilihat dari relasi guru dan murid yang semakin dekat dan murid tidak takut kepada guru setelah menerima masukan.

Pelaksanaan disiplin positif yang kedua menggunakan ketegasan. Sering kali murid mencari alasan agar guru bisa mentoleransi perilaku menyimpang yang dilakukan. Dalam penerapan guru tetap konsisten akan peraturan dan konsekuensi. Hal ini diimbangi dengan pengertian pada murid secara personal.

Pelaksanaan disiplin positif yang ketiga mengikutsertakan orangtua. Orangtua dan guru memiliki tujuan yang sama dalam pendidikan anak. Guru membantu membimbing pada waktu di sekolah, orang tua membantu meneruskan pembelajaran dari sekolah di rumah. Guru dan orangtua perlu bekerjasama agar tujuan pendidikan dan pembentukan karakter yang sejalan dengan Iman Kristen tertanam pada anak.

Pelaksanaan disiplin positif yang keempat guru mendorong murid percaya akan kemampuan diri sendiri. Dorongan guru berperan menolong murid memiliki pola pikir untuk bertanggung jawab atas dirinya sendiri. Guru mendorong murid untuk percaya bahwa Tuhan ikut ambil bagian dalam murid berproses dan mereka tidak berproses sendiri. Memiliki sikap disiplin membantu murid untuk tumbuh menjadi orang yang berkompeten. Guru mendorong murid untuk mandiri dan percaya akan potensi yang Tuhan sudah berikan dalam dirinya.

Integrasi Iman Kristen ini mampu menjadi dasar bagi murid untuk mengandalkan Tuhan. Ketika penerapan disiplin positif diterapkan, mampu menolong murid memiliki motivasi dari dalam untuk melakukan hal yang benar dan bertanggung jawab atas apa yang dia lakukan. Sehingga murid semakin memiliki gambaran teladan yang benar dan mampu menegakkan kebenaran dalam situasi apapun.

\section{DAFTAR PUSTAKA}


Adhi, Y., Winardi, Y., \& Listiani, T. (2018). Penerapan model integrasi biblika bryan smith tahap 2 pada pembelajaran matematika untuk meningkatkan pemahaman wawasan kristen alkitabiah (wak) siswa kelas xi ipa-2 di suatu sma di toraja [the implementation of the bryan smith stage 2 biblical integration model in learning mathematics to improve the understanding of a biblical christian worldview (bcw) of grade 11 science- 2 students in a high school in toraja]. JOHME: Journal of Holistic Mathematics Education, 2(1), 48.

Agregasi BBC Indonesia (2018, July 24). Kekerasan terhadap Siswa Masih Marak, Guru Berdalih 'demi Kedisiplinan'. Retrieved from:

https://news.okezone.com/read/ 2018/07/24/65/1926589/kekeras an- terhadap-siswa-masihmarak-guru-berdalih-demikedisiplinan

Aji, I. P., \& Tamba, K. P. (2020). Penerapan disiplin positif dalam pembelajaran ditinjau melalui perspektif kristen [positive discipline in learning reviewed through a christian perspective]. JOHME: Journal of Holistic Mathematics Education, 3(2), 218-219.

Berry, S, R. (1994). 100 ideas that work. Colorando, America: Association of Christian Schools International.

Burden, P. (2013). Classroom management: Creating a successful K-12 learning community (5th ed.). United States, America: Courier Kendallville.

Emiyati, A. (2018). Mendisiplin Anak Menurut Prinsip
Kristen. Evangelikal: Jurnal Teologi Injili dan Pembinaan Warga Jemaat, 2(2), 148, 154-155.

Febriandari, E. I. (2018). Penerapan metode disiplin positif sebagai bentuk pembinaan pendidikan karakter disiplin anak. Karya Ilmiah Dosen, 1(1). 156

Gunarsa, S, D. (2012). Dasar teori dan perkembangan anak. Jakarta: BPK Gunung Mulia.

Herdiansyah, H. (2013). Wawancara, observasi, dan focus groups: Sebagai instrument penggalian data kualitatif. Jakarta, Indonesia: PT Rajagrafindo.

Hidayat, N., Danarti, \& Darwati, S., (2016). Disiplin positif; membentuk karakter tanpa hukuman. The Progressive and Fun Education Seminar. 3 Agustus $2016 . \quad$ (473-474). Universitas Muhammadiyah Surakarta, Surakarta

Kurniasari, A. (2016). Kekerasan versus disiplin dalam pengasuhan anak. Sosio Informa, 1(2), 142-143.

Mahpur, M. (2017). Memantapkan analisis data kualitatif melalui tahapan koding.

Majelis Pendidikan Kristen di Indonesia. (2016). Pengantar interaksi belajar mengajar yang efektif. Jakarta: BPK Gunung Mulia.

Malia, I. (2018, May 18). PR Hari Pendidikan Nasional: Angka Kekerasan di Sekolah Masih Tinggi. Retrieved from:

https://www.idntimes.com/news/indon esia/indianamalia/hari-

pendidikan-kpai-kekerasan-disekolah/3

Marche, S. (2018, September 5). Why You Should Stop Yelling at Your Kids: It doesn't make you look authoritative. It makes you look out of control to your kids. It makes you look weak. Retrieved from:

https://www.nytimes.com/2018/09/05/ well/family/why-you-should-stopyelling-at-yourkids.html\#: :text=A\%202014\%20stud 
y\%20in\%20The, an\%20increase $\% 2$

0in\%20behavioral\%20problems

Nelsen, J. (N.d). Encouragement: What does it mean and how is it done? Retrieved from: https://www.positivediscipline.c om/articles/encouragementwhat-does-it-mean-and-how-itdone

Raco, J. (2018). Metode penelitian kualitatif: karakteristik jenis, keunggulannya. dan Indonesia: PT Gramedia Widiasarana Indonesia.

Ratnawati. (2018). Peranan Guru Sebagai Model Dalam Pembentukan Karakter Peserta Didik. "Pencegahan dan Penanganan Kekerasan Anak: Optimalisasi Peran Pendidik dalam Perspektif Hukum", 8 Mei 2018 (3). STKIP Andi Matappa Pangkep.

Shabir, M. (2015). Kedudukan guru sebagai pendidik: (tugas dan tanggung jawab, hak dan kewajiban, dan kompetensi guru). AULADUNA: Jurnal Pendidikan Dasar Islam,2(2), 222

Shihab, N. (2017). Keluarga kita: Mencintai dengan lebih baik. Tangerang, Indonesia: Penerbit Buah Hati.

Sidiq, U., \& Choiri, M. (2019). Metode Penelitian Kualitatif di Bidang Pendidikan. Ponorogo: CV. Nata Karya.

Sidjabat, B, S. (1994). Strategi pendidikan Kristen: suatu tinjauan teologis-filosofis. Jogjakarta, Indonesia: Yayasan ANDI.

Sitorus, J. P. (2018). Ragam bahasa dalam perspektif Alkitab
[Language variety from a Biblical perspective]. Polyglot: Jurnal Ilmiah, 14(2), 147.

Spokane Regional Health District, (2020). What is Positive Discipline. Retrieved from:https://srhd.org/media/documents /What20is20Positive20Discipline1. pdf

Ulfa, M. (2020). Peran Keluarga dalam Konsep Psikologi Perkembangan Anak Usia Dini. Aulad: Journal on Early Childhood, 4(2), 297.

Utsman. (2017). Validitas dan reliabilitas untuk mengevaluasi mutu penelitian kualitatif. Semarang: Universitas Negeri Semarang.

Wijaya, D, R. (2015). Disiplin positif dalam pengasuhan dan pendidikan. Bandung, Indonesia.

Windari, R. (2016). Penggunaan Hukum Disiplin (Corporal Punishment) pada Anak Di Lingkungan Sekolah Dalam Perspektif Hukum Pidana di Indonesia. Jurnal Hukum PRIORIS, 4(3), 305-306. 